\title{
Comparative nutritional condition of larval dab Limanda limanda and lesser sandeel Ammodytes marinus in a highly variable environment
}

\author{
Arne Michael Malzahnn ${ }^{1, *}$, Catriona Clemmesen ${ }^{2}$, Karen Helen Wiltshire ${ }^{1}$, \\ Silke Laakmann ${ }^{1,3}$, Maarten Boersma ${ }^{1,4}$
}
${ }^{1}$ Alfred Wegener Institute for Polar and Marine Research, Biologische Anstalt Helgoland, Ostkaje 1118, 27498 Helgoland, Germany ${ }^{2}$ Leibniz Institute of Marine Sciences (IFM-GEOMAR), Düsternbrooker Weg 20, 24105 Kiel, Germany
${ }^{3}$ University of Bremen, Bibliothekstraße 1, 28359 Bremen, Germany
${ }^{4}$ GKSS Research Centre, Institute for Coastal Research, Max-Planck-Straße 1, 21502 Geesthacht, Germany

\begin{abstract}
We investigated the nutritional condition of larval fishes caught in daily ichthyoplankton hauls in the 'Helgoland Roads' (54 $11.18^{\prime} \mathrm{N}$ and $07^{\circ} 54.00^{\prime} \mathrm{E}$ ) from February to June 2004 . We concentrated on larvae of dab Limanda limanda and lesser sandeel Ammodytes marinus in order to compare early life stages of iteroparous and nearly semelparous fish. We analysed length, weight and RNA:DNA ratios as a proxy for condition of the larvae. The relationship between larval nutritional condition and larval size provided an indication of condition-selective mortality due to a loss of larvae in poor condition from the larger size-classes. For the sandeel, larvae in good condition were present in all size-classes, whereas for the dab maximum larval condition increased with increasing size. Variability in both standard length and condition was high in the 2 species during their planktonic stage. Both species showed good nutritional condition in the early to mid portion of the recruitment period and declines in condition in late April. This was more pronounced in larval dab, which showed a higher dependency on feeding conditions than larval sandeel. Together, these findings indicate a more conservative strategy of early life stages of the nearly semelparous sandeel compared with the iteroparous dab.
\end{abstract}

KEY WORDS: Larval fishes · RNA:DNA ratio $\cdot$ Helgoland Roads $\cdot$ North Sea

\section{INTRODUCTION}

The only noteworthy parental care numerous larval fish species receive are the energy reserves contained in the egg. This initial parental gift to their descendants varies among species and between different types of eggs. Demersal (sinking or deposited on the bottom) eggs are richer in energy than pelagic eggs of the same size (Loenning et al. 1988) and, as they are usually larger in size than pelagic eggs, even more energy-rich. Larvae that hatch from these high-energy demersal eggs can thus cope better with unfavourable nutritional conditions than those larvae which emerge from smaller eggs (Einum \& Fleming 2000). Moreover, variability in environmental conditions should select for larger egg sizes (McGinley et al. 1987). Short-lived species, with only 1 or 2 spawning events during their lifetime, should ideally have an evolutionary history such that a specific proportion of larval survival is guaranteed under all circumstances. The reason for this is that the relative importance of a single spawning event is higher than in long-lived species, which have a more iteroparous life-history. We thus hypothesise that short-lived species, living in highly variable environments, will have adapted to more conservative reproductive strategies through the production of larger eggs, longer spawning periods and longer transition phases from internal to external feeding to 
ensure that at least subsets of their offspring will survive.

The performance of fish larvae can be assessed in many different ways. Examples include enzyme activity, otolith growth, or the ratio between RNA and DNA in tissue. In this study, we assessed the condition of larval fishes by analysis of the ratio between their RNA and DNA content, a method commonly used in larval ecology and fisheries research (Clemmesen \& Doan 1996, Pepin et al. 1999, Malzahn et al. 2003, Voss et al. 2006). The general assumption is that the amount of DNA per cell is constant, whereas the amount of RNA per cell varies with anabolic activity. This ratio has the advantage that it integrates the feeding history over a period of approximately $3 \mathrm{~d}$ (Clemmesen 1994), which makes it robust against short-term effects such as those shown for digestive enzymes (Ferron \& Leggett 1994). The RNA:DNA ratio can be used in several ways, as a tool to investigate nutritional condition and survival potential in laboratory experiments (Clemmesen 1994, St. John et al. 2001), and in field studies (Bulow 1987) by comparing the ratios itself. Another widespread and promising use is its predictive power for protein growth where species-specific models are available (Buckley 1984, Caldarone et al. 2003, Buckley et al. 2004, Caldarone 2005). One consideration, however, is the temperature-dependence of the RNA:DNA ratio itself. Higher RNA:DNA values at lower temperatures are believed to be a compensatory mechanism for the reduced activity of the anabolic machinery (Goolish et al. 1984). This makes comparisons over a wide range of temperatures (and hence in field studies) difficult, as the same RNA:DNA value may reflect a different condition at different temperatures. Indeed, Malzahn et al. (2003) reported significant differences in RNA:DNA between larval coregonid fishes reared under ad libitum food supply at 2 different temperatures $\left(8\right.$ and $18^{\circ} \mathrm{C}$ ). However, albeit statistically significant, the differences in RNA:DNA were only around 0.03 per centigrade degree, whereas studies with different food levels often report differences in RNA:DNA ranging from 1 to 3 in comparisons between fed and unfed larvae (Suneetha et al. 1999). Hence, RNA:DNA as a measure of nutritional condition can be used for larvae with different thermal backgrounds.

Our hypothesis that shorter-lived species have more conservative reproductive strategies translates directly into the prediction that larvae of short-lived species should be more independent of current feeding conditions. We tested this prediction by contrasting larval stages of the lesser sandeel Ammodytes marinus and the dab Limanda limanda investigating their condition in the light of prevailing environmental conditions. The lesser sandeel is a short-lived species. It comprises up to one-third of the total fishery yield in the North Sea (Arnott \& Ruxton 2002) and is a major food source for several predatory fish (Carruthers et al. 2005) and bird species (Furness 2002). Sandeels normally reproduce in their second year; they produce large demersal eggs and, because of extremely high natural mortality, do not live much longer than $3 \mathrm{yr}$. As a contrast to their larval performance we chose the temporally co-occurring dab, which spawns several times during its lifetime of around $10 \mathrm{yr}$, producing smaller pelagic eggs. It is generally accepted that in flatfishes the relative importance of the larval stages is of minor importance compared to the density-dependent mechanisms acting on the settled juveniles, which normally dampens year-class strength variations (Van der Veer et al. 2000). Hence, we would expect lesser sandeel larvae to grow better and show fewer starvation symptoms under various biological and physical conditions than larval dab.

\section{MATERIALS AND METHODS}

The ichthyoplankton community was surveyed on a daily (Mon-Fri) basis at $54^{\circ} 11.18^{\prime} \mathrm{N}$ and $07^{\circ} 54.00^{\prime} \mathrm{E}$, known as 'Helgoland Roads'. The station is located between the island of Helgoland and an adjacent dune, in the German Bight, North Sea. Double oblique hauls were carried out using a CalCOFI ring trawl equipped with $500 \mu \mathrm{m}$ mesh net (aperture $100 \mathrm{~cm}$, length $400 \mathrm{~cm}$, equipped with a flow meter) from a research vessel. The gear was deployed for $15 \mathrm{~min}$ per sampling. Water depth at the station is approximately $8 \mathrm{~m}$ and the water column is mixed throughout the year by strong tidal currents (up to 1.5 knots). On board the research vessel, the sample was gently flushed into a bucket, in which it was transferred to the Alfred Wegener Institute on Helgoland. As the station sampled is approximately $200 \mathrm{~m}$ away from the Institute and the ichthyoplankton haul always comprised the last deployment before heading back to the Institute, samples usually arrived at the laboratory within 15 min. The samples were sieved and transferred to a Bogorov chamber and larval fishes were sorted out using a stereo microscope (Olympus B061). All larvae (or in cases with high densities of certain fish species, the first 50 larvae per species found in the Bogorov chamber) were frozen at $-80 \mathrm{C}^{\circ}$ in Eppendorf vials for further analysis. The whole procedure, from hauling in the net to freezing the samples, took no longer than 45 min. Samples of Ammodytes marinus and Limanda limanda for biochemical analysis were taken during the whole period of larval occurrence in the plankton, which was from 4 February to 4 May 2004 for sandeel and from 18 February to 23 June 2004 for dab. 
Zooplankton samples were taken using a $150 \mu \mathrm{m}$ mesh net (aperture $17 \mathrm{~cm}$, length $100 \mathrm{~cm}$, equipped with a flow meter) hauled vertically through the water column by hand. Zooplankton samples were taken weekly from 15 January to 12 February 2004 and twice weekly from 17 February to 29 June 2004. Zooplankton data were pooled as suitable prey organisms for larval fishes based on their size, whereby all zooplankters smaller than $300 \mu \mathrm{m}$ were considered as potential food sources for larval fishes. As different size-classes of fish larvae were present in all catches, no further division into specific plankton size-classes was conducted. Weekly means of diatom carbon were calculated from daily phytoplankton counts following Hillebrand et al. (1999). Sea surface temperature was measured daily using a mercury thermometer (Wiltshire \& Manly 2004).

RNA and DNA concentrations were analysed using a modification of the method of Clemmesen et al. (2003). Samples of lesser sandeel and dab were thawed and standard length was measured using a stereomicroscope. Larvae were freeze-dried to constant weight (16 h, using a Christ Alpha $1-4$ freeze-drier at $-51^{\circ} \mathrm{C}$ ) and weighed to the nearest $0.0001 \mathrm{mg}$ (Sartorius microbalance SC2). The freeze-dried larvae were rehydrated in Tris-SDS-buffer (Tris $0.05 \mathrm{M}, \mathrm{NaCl}$ $0.01 \mathrm{M}$, EDTA $0.01 \mathrm{M}$, SDS $0.01 \%$ ) for $15 \mathrm{~min}$. Cells were disrupted by shaking in a cell mill with differentsized glass beads (diameter $2 \mathrm{~mm}$ and 0.17 to $0.34 \mathrm{~mm}$ ) for $15 \mathrm{~min}$. The homogenate was then centrifuged at $6000 \mathrm{rpm}$ at $0^{\circ} \mathrm{C}$ for $8 \mathrm{~min}$, and the supernatant used for analysis. The amount of nucleic acids was measured fluorometrically in a microtitre fluorescence reader (Labsystems, Fluorescan Ascent) using the fluorophore ethidium bromide. Total nucleic acids were measured first, and RNase was then applied to the sample to digest the RNA. After the enzyme treatment (30 min at $37^{\circ} \mathrm{C}$ ) the remaining DNA was measured. RNA fluorescence was calculated by subtracting DNA fluorescence from the total nucleic acid fluorescence. RNA calibrations were carried out each day. The DNA concentrations were calculated using the relationship between RNA and DNA fluorescence described by Le Pecq \& Paoletti (1966). All steps were done on ice.

The approach of this paper was to detect small changes in condition, which can potentially be lost in statistical approaches based on means. These changes are normally found at the extremes of distributions and usually have only minor effects on common statistical tests. Hence, for the detection of these small-scale changes in distribution patterns of the parameters analysed, a nonparametric approach proposed by Pepin et al. (1999) was used. This approach examines how the probability distribution of a random variable $y$ depends on some other variable $\boldsymbol{x}_{\text {, }}$ without any assumptions about the form of the distributions or about the form of the dependence. The goal is achieved by estimating cumulative probability distributions and by computing local influences of $x$ on $y$. This is based on the idea of locally weighted estimates of the cumulative probability distribution by kernel smoothing (Pepin et al. 1999, Evans 2000). In this study the scatter between the 10th percentile (lower extreme) and the 90th percentile (upper extreme) of the distribution was analysed. This was done by creating 500 synthetic data sets originating from a random assignment of pairs of variables (length and RNA:DNA ratio) from the original data set and by performing Monte Carlo simulations to examine the probability that the patterns of change in the cumulative probability distribution of the original data are caused by chance alone.

\section{RESULTS}

\section{Environmental conditions}

The water temperature at the sampling site dropped from $6^{\circ} \mathrm{C}$ in early January to $3^{\circ} \mathrm{C}$ in early March and increased to $12^{\circ} \mathrm{C}$ by the end of May (Fig. 1). Zooplankton data were pooled as suitable prey organisms for larval fishes, using the $>300 \mu \mathrm{m}$ criterion, which yielded a combination of meroplanktonic larvae (Asteroidea, Aphroditidae, Polychaeta, Gastropoda, Bryozoa, Balanidae) and holoplankters (Cladocera [Evadne spp., Podon spp.] and naupliar and copepodite stages of several copepod species). Total potential prey densities increased from January to the middle of April from 1.2 to 10 individuals $\mathrm{l}^{-1}$. This increase was followed by a steep drop in density to around 2 zooplankters $\mathrm{l}^{-1}$ within just 1 wk around 20 April 2004 (Fig. 1). The collapse of zooplankton abundance was

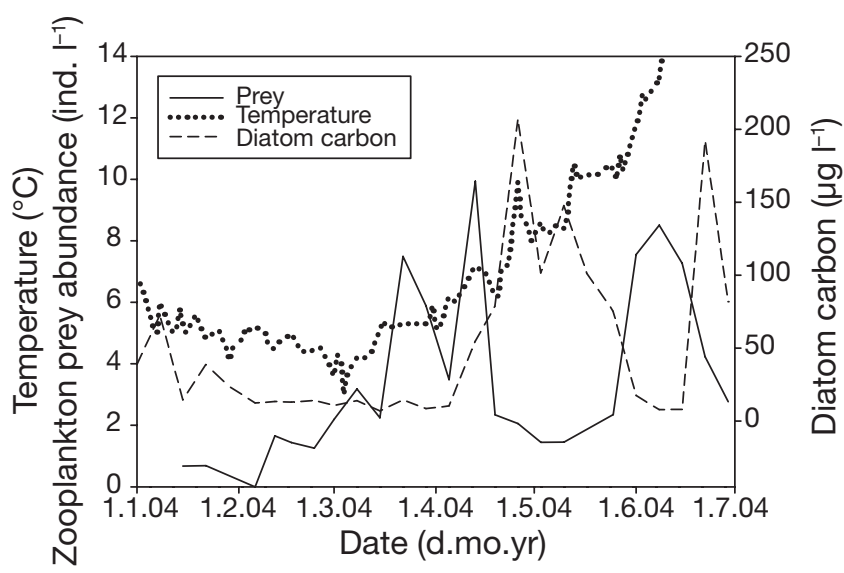

Fig. 1. Development of zooplankton prey, temperature and diatom carbon at sampling site in Helgoland Roads 
directly followed by a sharp increase in phytoplankton biomass from 25 to $215 \mu \mathrm{g}$ diatom carbon $\mathrm{l}^{-1}$ (Fig. 1), which could indicate top-down mechanisms acting on phytoplankton growth in spring 2004.

\section{Species occurrence}

Lesser sandeel larvae first occurred in the ichthyoplankton in early February. In general, February was characterised by high sandeel numbers in the catches, ranging from 2 to 50 individuals $\mathrm{m}^{-3}$. A second peak in sandeel abundance was observed in early, middle and late March with densities of up to 8 individuals $\mathrm{m}^{-3}$. Thereafter, numbers remained low at 0.01 to 0.1 larvae $\mathrm{m}^{-3}$ until the last larva was caught in the beginning of May (Fig. 2). Larval dab were first caught at the end of February and their mean abundance in 2004 was 0.2 individuals $\mathrm{m}^{-3}$. Two distinct peaks in dab abundance were observed in the middle of March and at the end of April, with densities of up to 1 larva $\mathrm{m}^{-3}$. From April until late June, when the last dab larva was caught, abundance remained low.

\section{Nutritional condition of dab}

Standard length, dry weight and RNA:DNA were analysed for a total of 419 larval dab. Variability in their standard length was high but fairly constant throughout the whole period of their occurrence in the plankton (Fig. 3). None of the flatfish larvae analysed in this study showed any signs of asymmetry (an indicator of imminent settlement). A high proportion of larvae in better condition were found in the middle of the sampling period. This caused a steady elevation of the 90th percentile of the RNA:DNA distribution until the

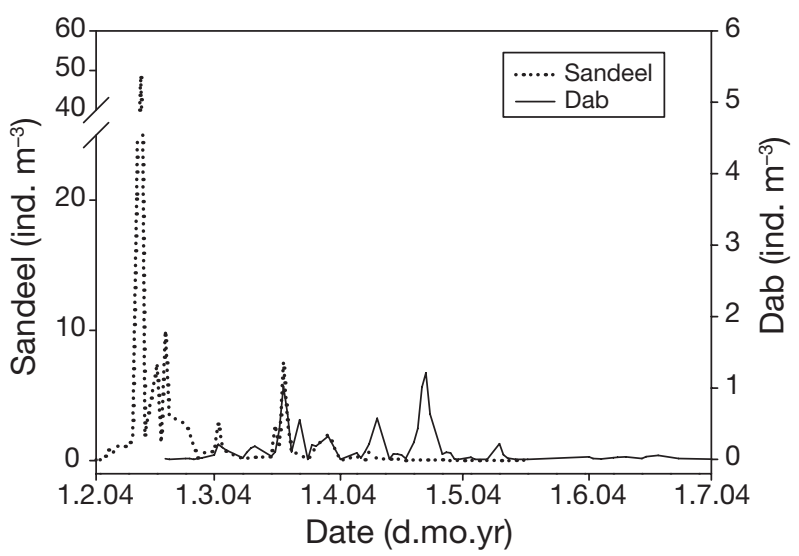

Fig. 2. Ammodytes marinus and Limanda limanda. Abundance of lesser sandeel and dab larvae. Note different scales for the 2 species

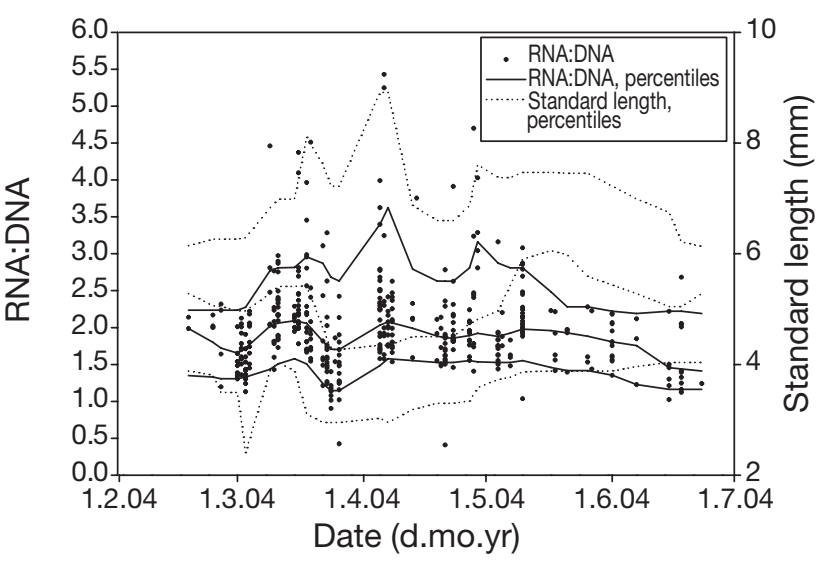

Fig. 3. Limanda limanda. RNA:DNA and standard length over time. Curves for RNA:DNA and standard length from bottom to top: 10 th, 50th and 90th percentiles

middle of April. While the lower parts of the RNA:DNA distribution (indicated by the 10th and 50th percentiles) decreased just slightly from 20 April onwards, larvae in better condition were lacking later in the season. This resulted in a sharp decrease in the 90th percentile. As a result, the mean RNA:DNA decreased.

In order to distinguish between periods of high and low food availability (before and after 20 April, see also Fig. 1), we compared the slopes of the regression lines relating length with RNA:DNA from the 46 larvae caught within the $2 \mathrm{wk}$ prior to and the 78 larvae caught within $2 \mathrm{wk}$ following the breakdown in zooplankton abundance. The standard length of the larvae was included into the analysis to investigate whether all sizeclasses were affected in the same way by the reduction of zooplankton prey. The temperature difference between the 2 weeks was $2.1^{\circ} \mathrm{C}$. The slopes of the regression lines before and after 20 April were significantly different, with higher slopes observed in larvae caught before the breakdown in food availability on 20 April (0.53 vs. 0.18) (Fig. $4 ; \mathrm{p}<0.01$ ). Further analyses of the RNA:DNA of larvae smaller than $4 \mathrm{~mm}$, before and after food deprivation, revealed no significant difference in RNA:DNA values (Student's $t$-test, $\mathrm{p}>0.05$ ) indicating that larger larvae were affected by the decrease in prey availability, while smaller larvae were not.

\section{Nutritional condition of sandeel}

In contrast to dab size distribution, the variability and the standard length of the 366 sandeel larvae analysed increased over time. A constant supply of small larvae maintained the 10th percentile at roughly $5 \mathrm{~mm}$ while the 50th and 90th percentiles increased until the middle of April, reaching values between 11 and $14 \mathrm{~mm}$ (50th and 90th percentiles respectively) (Fig. 5). Late in the 


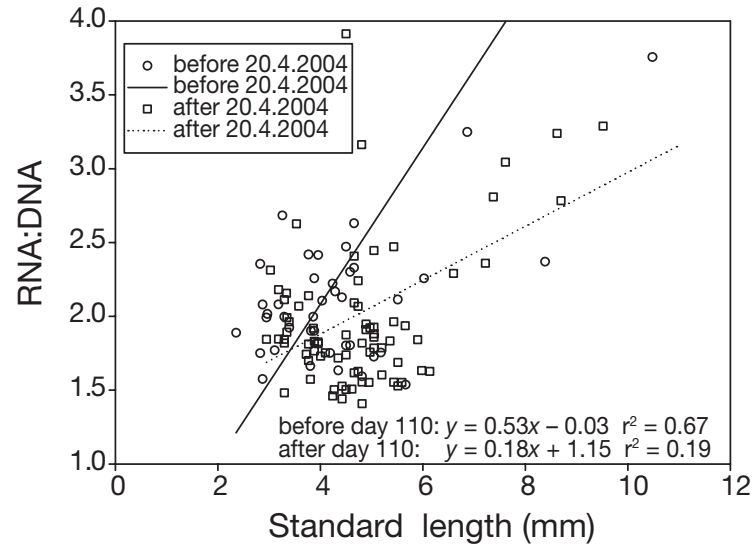

Fig. 4. Limanda limanda. Relationship of RNA:DNA and standard length of larval dab divided into categories $2 \mathrm{wk}$ prior to and 2 wk following 20 April 2004, when phytoplankton biomass increased sharply in response to a collapse in zooplankton abundance

season a decrease in larval length due to a lack of larger larvae in the catches was observed. The RNA:DNA in larval lesser sandeel was highly variable throughout the season, ranging from 2 to 9. The amount of data available for the period after the middle of April is low, but nevertheless, no RNA:DNA value greater than 4 was found in the 16 larvae caught in the last $30 \mathrm{~d}$ of the sandeel season, a value well below the mean RNA:DNA for the whole season (Fig. 5).

\section{Interspecific comparisons}

Analysis of the relationship between larval size and RNA:DNA revealed different patterns for both species. In both species the 50th percentile increased with increasing larval size. In sandeel, this elevation was

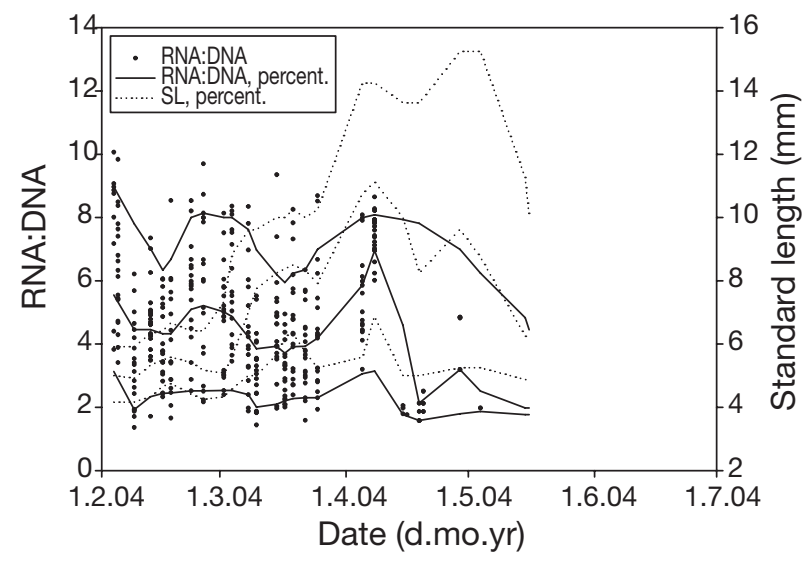

Fig. 5. Ammodytes marinus. RNA:DNA ratio and standard length of larval sandeel over time. Curves for RNA:DNA and standard length (SL) from bottom to top: 10th, 50th and 90th percentiles (percent.) caused by the loss of larvae in poor condition, with maximal ratios remaining constant (Fig. 6). Larval dab also showed a loss of larvae in poor condition but, in contrast to sandeel, a massive increase in the RNA:DNA maxima with increasing size (Fig. 7). The probability that the observed scatter between the 10th and the 90th percentile of the length and RNA:DNA ratio relationship is produced by chance alone ranged between 5 and $20 \%$ for larger sandeel (Fig. 8), indicating that, indeed, only the fittest individuals survived in the larger sandeel size-classes. For dab, a probability of nearly $100 \%$ for the larger size-classes was calculated, which means that the scatter was significantly higher than the average scatter of the data set (Fig. 9). This reflects the large scatter and the evenly distributed RNA:DNA ratios of the larger size-classes of dab. The high probability of the scatter being larger than the average scatter of the data set indicates that this elevation in scatter was caused by the increase in larvae of extremely good condition that were not present in the smaller size-classes of the population.

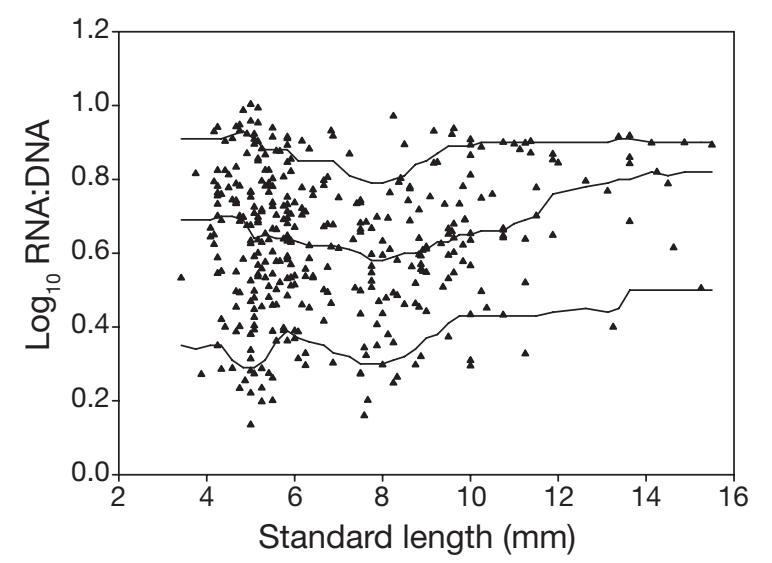

Fig. 6. Ammodytes marinus. RNA:DNA and standard length of larvae. Curves from bottom to top: 10th, 50th and 90th percentiles

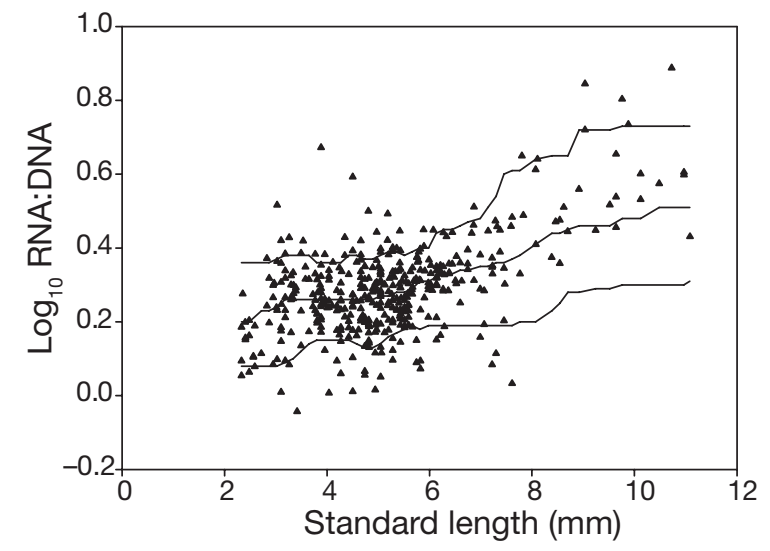

Fig. 7. Limanda limanda. RNA:DNA and standard length of larvae. Curves from bottom to top: 10th, 50th and 90th percentiles 


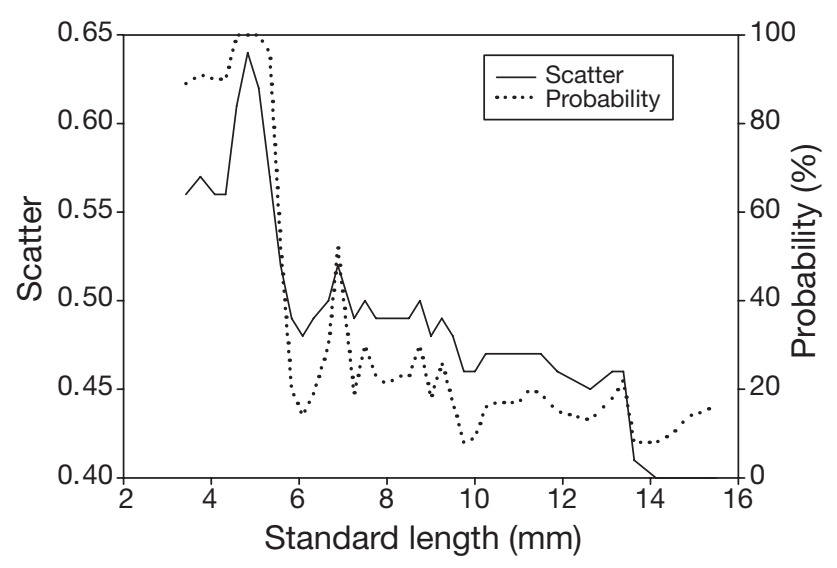

Fig. 8. Ammodytes marinus. Larval length vs. scatter between 10th and 90th percentiles of RNA:DNA and probability of measuring estimated scatter relative to randomisation of the data

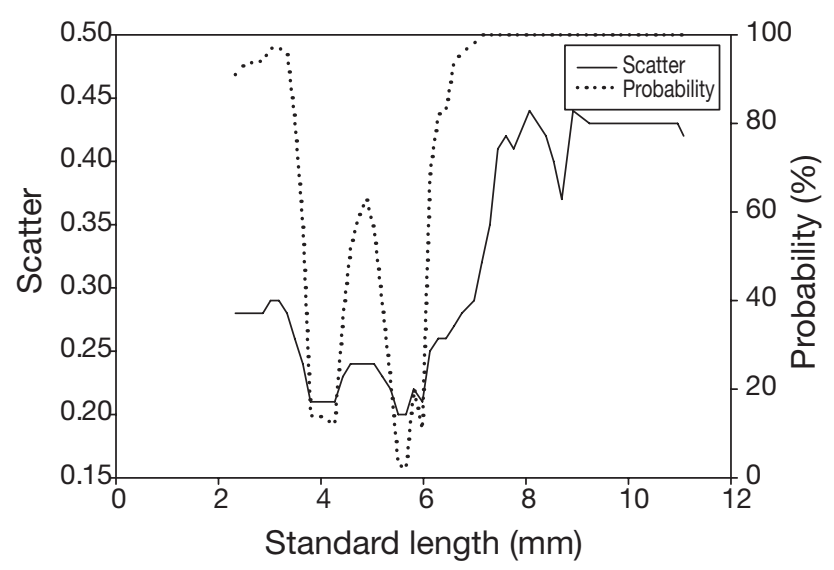

Fig. 9. Limanda limanda. Larval length vs. scatter between 10th and 90th percentiles of RNA:DNA and probability of measuring estimated scatter relative to randomisation of the data

\section{DISCUSSION}

This study provides insights into the early life history of 2 fish species with contrasting reproductive strategies in the North Sea. Both species are characterised by a similar seasonality and both have a prolonged hatching season compared to other species in this region, which presumably represents a bet-hedging strategy to deal with high variability in environmental conditions. Since feeding conditions are variable intraand interannually, bet-hedging seems a good strategy. In 2004, those larvae that hatched before mid-April seemed to constitute the survivors. However, as the timing of the zooplankton peak is generally highly variable, it is likely that in other years larvae that hatch at different times comprise the survivors.

Although a prolonged period between sampling and freezing of samples may influence the RNA:DNA ratio, this was not a problem in our study, since the timeframe between sampling and freezing was usually in the order of $45 \mathrm{~min}$. During this time, the larvae were exposed to ambient temperatures on board and stored on ice upon arrival in the laboratory. Moreover, a study by Ferguson \& Drahushchack (1989) showed that even leaving material for nucleic acid analysis on wet ice or in water of 8.5 to $9.5^{\circ} \mathrm{C}$ for up to $24 \mathrm{~h}$ did not cause significant degradation of either RNA or DNA. Hence, no significant breakdown of nucleic acids occurred in our samples prior to the analysis.

Low food availability at low temperatures early in the season does not necessarily mean that this constitutes adverse conditions. Since growth is, however, accelerated by increasing temperature, low temperature conditions result in slow growth, leading to a longer persistence of the most vulnerable larval stages and a prolonged phase of high predation risk. Later in spring, temperature and food availability usually rise; a pattern clearly reflected by the higher condition of both dab and sandeel in early April. In 2004, we observed a drastic reduction in food availability from the middle of April to the end of May. This may have had several consequences for the larval fishes: not only did they run the risk of starvation, but the risk of predation increased with decreasing condition. Later in the season, the larvae faced better feeding conditions following the recovery of zooplankton abundance; however, their condition did not improve in response to this increased prey abundance. This could be the result of changes in nutritional quality of the zooplankton as food for larval fishes, and/or a result of higher temperatures, which were potentially outside the optimal temperature range for the investigated larvae. Thus, during this period, the larvae were not able to utilise the abundant food supply for growth.

Consequently, only a short period of the year yielded favourable conditions for the larval fish species in our study, a pattern already proposed by Hjort (1914) and Cushing $(1974,1990)$. In fact, several studies concentrating on growth rates or hatch date distribution derived from otolith readings revealed similar results. Baumann et al. (2003) found the highest growth rates and thus the highest survival probability of radiated shanny Ulvaria subbifurcata at intermediate temperatures. Wright \& Bailey (1996) compared the observed hatch dates of larval sandeel and back-calculated hatch dates derived from otolith microstructures of juvenile sandeel in 3 consecutive years. They found that the survivors' hatch dates differed somewhat between years; an early hatch comprised the survivors in 1990, a late hatch in 1991 and an intermediate hatch in 1992. They concluded that there was an indication for a seasonal cycle of growth opportunity in the $3 \mathrm{yr}$ of their investigation, that interannual differences occur 
and that a coupling of hatching and the onset of secondary production may be an important factor in yearclass variability. The results of our study also showed strong seasonality in larval condition but, in contrast to Cushing's $(1974,1990)$ predictions, the period of highest larval condition was not at the peak of food availability but 2 to 3 wk earlier.

In general, low food availability is known to lead to reduced growth and increased mortality in larval fishes (Clemmesen 1994, St. John et al. 2001). In this study, low RNA:DNA was found to be linked to poor feeding conditions only at times of an extreme decrease in food availability. Indeed, the slope of the length-condition regression was significantly higher in the period before the breakdown in food availability than in the 2 food-deprived weeks. The temperature difference during this 4 wk timeframe was within the window of direct comparability of RNA:DNA ratios (Caldarone et al. 2003), and thus it is unlikely that temperature-related effects can explain the results. In fact, our findings show that larger larvae suffered from poor feeding conditions while smaller larvae showed no significant decline with decreasing prey abundance. Suneetha et al. (1999) reported less serious starvation effects in small herring larvae Clupea harengus than in larger ones and attributed this to benefits derived from yolk remnants. This fits well with our findings that smaller larvae were not affected by the decline in zooplankton prey density. They may have benefited from their ability to utilise 2 sources of energy, internal yolk reserves and external food. Additionally, young stages of larval fishes are known to feed on phytoplankton in the first days of external feeding. This has been shown in various field observations (Last 1978, Monteleone \& Peterson 1986) and controlled experiments (van der Meeren 1991a). Van der Meeren (1991a) showed that for first-feeding cod Gadus morhua larvae this uptake of phytoplankton organisms was the result of active filter-feeding and not accidental in nature. Nevertheless, the nutritive value of phytoplankton for larval fishes is considered low (May 1970), and hence, it is unlikely that larval fishes can acquire their whole energy demand from autotrophic organisms. However, they may derive some essential components from the algal diet and at least compensate shortages of zooplankton food (van der Meeren 1991a). Further, small larvae regularly prey on protists (van der Meeren 1991b). Although no data on protozoan abundance are available for the months under investigation, it is likely that as a response to the diatom bloom the abundance of heterotroph protists in the system increased. As these are in the size range of copepod nauplii, protists are predominantly consumed by smaller fish larvae, while larger larvae select older copepodite stages. Thus it can be hypothesised that the smaller larvae of this study may have switched food sources in order to exploit the rapidly increasing diatom biomass.

The relationship between maximum larval nutritional condition and size showed a different pattern in the 2 species under investigation. Larval dab showed a clear increase in condition with increasing size. Similar patterns were shown by Clemmesen et al. (2003) for Atlantic cod larvae in mesocosm studies. The pattern of displaying the same maximum condition at all larval size-classes, as found for lesser sandeel in this study, was previously reported by Pepin et al. (1999) for several species from Conception Bay, Newfoundland. In their study, they demonstrated condition-dependent mortality showing that maximum condition remained constant with growth but that larvae in poor condition were lacking in the larger size-classes. The species with the clearest condition-dependent mortality in the investigation of Pepin et al. (1999) were short-lived species. The production of larvae in maximum condition at the time of hatch can be interpreted as a more conservative strategy than that of producing larvae far below their maximum possible condition at hatch, which first have to develop a good condition.

Larval sandeel, representative of a short-lived fish species, did not show a strong dependency on high prey density and performed well under various food/ temperature conditions. Only at the end of the season did we detect a deterioration in larval condition coinciding with decreasing prey levels. In general, high temperatures are considered counterproductive for sandeel production. Arnott \& Ruxton (2002) found a negative correlation between sandeel recruitment and water temperature in the North Sea, with strongest effects in the southern part of the North Sea, which represents the southernmost distribution limit of this species. In contrast, a positive relationship between condition and prey availability was found in dab, representative of a long-lived species, indicating a higher dependence on environmental factors in this species.

Our hypothesis that short-lived species have more conservative reproductive strategies than long-lived forms is supported by the fact that sandeels produce large, energy-rich eggs as well as by their long transition period from internal to external feeding. To summarise, these adaptive characteristics indicate a relatively high independence of sandeels from environmental factors such as temperature and/or prey densities, thus enabling this short-lived fish species to produce larvae in good condition.

Acknowledgements: We thank the crew of the RV 'Aade' for the daily plankton hauls, even in severe weather conditions, and Silvia Janisch for her patient phytoplankton enumeration. This work was carried out under the auspices of the Helgoland Foodweb Project. This study complies with the current German law on animal studies. 


\section{LITERATURE CITED}

Arnott SA, Ruxton GD (2002) Sandeel recruitment in the North Sea: demographic, climatic and trophic effects. Mar Ecol Prog Ser 238:199-210

Baumann H, Pepin P, Davidson FJ, Mowbray F, Schnack D, Dower JF (2003) Reconstruction of environmental histories to investigate patterns of larval radiated shanny (Ulvaria subbifurcata) growth and selective survival in a large bay of Newfoundland. ICES J Mar Sci 60:243-258

Buckley LJ (1984) RNA-DNA ratio: an index of larval fish growth in the sea. Mar Biol 80:291-298

Buckley LJ, Caldarone EM, Lough RG (2004) Optimum temperature and food-limited growth of larval Atlantic cod (Gadus morhua) and haddock (Melanogrammus aeglefinus) on Georges Bank. Fish Oceanogr 13:134-140

Bulow FJ (1987) RNA-DNA ratios as indicators of growth in fish: a review. In: Summerfelt RC, Hall GE (eds) Age and growth of fish. Iowa State University Press, Ames, IA, p 45-64

Caldarone EM (2005) Estimating growth in haddock larvae Melanogrammus aeglefinus from RNA:DNA ratios and water temperature. Mar Ecol Prog Ser 293:241-252

Caldarone EM, St. Onge-Burns J, Buckley LJ (2003) Relationship of RNA/DNA ratio and temperature to growth in larvae of Atlantic cod Gadus morhua. Mar Ecol Prog Ser 262:229-240

Carruthers EH, Neilson JD, Waters C, Perley P (2005) Long term changes in the feeding of Pollachius virens on the Scotian Shelf: responses to a dynamic ecosystem. J Fish Biol 66:327-347

Clemmesen C (1994) The effect of food availability, age or size on the RNA/DNA ratio of individually measured herring larvae: laboratory calibration. Mar Biol 118:377-382

Clemmesen C, Doan T (1996) Does otolith structure reflect the nutritional condition of a fish larva? Comparison of otolith structure and biochemical index (RNA/DNA ratio) determined on cod larvae. Mar Ecol Prog Ser 138:33-39

Clemmesen C, Buehler V, Carvalho G, Case R, and 10 others (2003) Variability in condition and growth of Atlantic cod larvae and juveniles reared in mesocosms: environmental and maternal effects. J Fish Biol 62:706-723

Cushing DH (1974) The natural regulation of fish populations. In: Harden Jones FR (ed) Sea fisheries research. Paul Elek, London, p 399-412

Cushing DH (1990) Plankton production and year-class strength in fish populations: an update of the match/mismatch hypothesis. Adv Mar Biol 26:249-294

Einum S, Fleming IA (2000) Highly fecund mothers sacrifice offspring survival to maximize fitness. Nature 405: 565-567

Evans G (2000) Local estimation of probability distribution and how it depends on covariates. Canadian Stock Assesment Secretariat Res Doc 200/120:11pp. Available at: www.dfo-mpo.gc.ca/csas

Ferguson MM, Drahushchak LR (1989) Effects of tissue collection and storage methods on nucleic acid determinations in white muscle of fishes. Trans Am Fish Soc 118: 709-713

Ferron A, Leggett WC (1994) An appraisal of condition measures for marine fish larvae. Adv Mar Biol 30:217-303

Furness RW (2002) Management implications of interactions

Editorial responsibility: Howard Browman (Associate Editorin-Chief), Storebø, Norway between fisheries and sandeel-dependent seabirds and seals in the North Sea. ICES J Mar Sci 59:261-269

Goolish EM, Barron MG, Adelman IR (1984) Thermoacclimatory response of nucleic acid and protein content of carp muscle tissue: influence of growth rate and relationship to glycine uptake by scales. Can J Zool 62:2164-2170

Hillebrand $H$, Duerselen CD, Kirschtel D, Pollingher U, Zohary $\mathrm{T}$ (1999) Biovolume calculation for pelagic and benthic microalgae. J Phycol 35:403-424

Hjort J (1914) Fluctuations in the great fisheries of Northern Europe. Rapp P-V Réun Cons Int Explor Mer 20:1-228

Last JM (1978) The food of four species of pleuronectiform larvae in the eastern English Channel and southern North Sea. Mar Biol 45:359-368

Le Pecq JB, Paoletti C (1966) A new fluorometric method for RNA and DNA determination. Anal Biochem 17:100-107

Loenning S, Kjoersvik E, Falk-Petersen IB (1988) A comparative study of pelagic and demersal eggs from common marine fishes in northern Norway. Sarsia 73:49-60

Malzahn AM, Clemmesen C, Rosenthal H (2003) Temperature effects on growth and nucleic acids in laboratoryreared larval coregonid fish. Mar Ecol Prog Ser 259: 285-293

May RC (1970) Feeding larval marine fishes in the laboratory: a review. Calif Coop Ocean Fish Investig Rep 14:76-83

McGinley MA, Temme DH, Geber MA (1987) Parental investment in offspring in variable environments: theoretical and empirical considerations. Am Nat 130:370-398

Monteleone DM, Peterson WT (1986) Feeding ecology of American sand lance Ammodytes americanus larvae from Long Island Sound. Mar Ecol Prog Ser 30:133-143

Pepin P, Evans GT, Shears TH (1999) Patterns of RNA/DNA ratios in larval fish and their relationship to survival in the field. ICES J Mar Sci 56:697-706

St. John MA, Clemmesen C, Lund T, Köster T (2001) Diatom production in the marine environment: implications for larval fish growth and condition. ICES J Mar Sci 58: 1106-1113

Suneetha KB, Folkvord A, Johannessen A (1999) Responsiveness of selected condition measures of herring, Clupea harengus, larvae to starvation in relation to ontogeny and temperature. Environ Biol Fish 54:191-204

van der Meeren T (1991a) Algae as first food for cod larvae, Gadus morhua L.: filter feeding or ingestion by accident? J Fish Biol 39:225-237

van der Meeren T (1991b) Selective feeding and prediction of food consumption in turbot larvae (Scophthalmus maximus L.) reared on the rotifer Brachionus plicatilis and natural zooplankton. Aquaculture 93:35-55

Van der Veer HW, Berghahn R, Miller JM, Rijnsdorp AD (2000) Recruitment in flatfish, with special emphasis on North Atlantic species: progress made by the flatfish symposia. ICES J Mar Sci 57:202-215

Voss R, Clemmesen C, Baumann H, Hinrichsen HH (2006) Baltic sprat larvae: coupling food availability, larval condition and survival. Mar Ecol Prog Ser 308:243-254

Wiltshire KH, Manly BFJ (2004) The warming trend at Helgoland Roads, North Sea: phytoplankton response. Helgol Mar Res 58:269-273

Wright PJ, Bailey MC (1996) Timing of hatching in Ammodytes marinus from Shetland waters and its significance to early growth and survivorship. Mar Biol 126:143-152

Submitted: May 31, 2006; Accepted: August 21, 2006

Proofs received from author(s): March 9, 2007 